\title{
Gendered impacts of extended working life on the health and economic wellbeing of older workers
}

\author{
Áine Ní Léime ${ }^{1 \star}$ and Jim Ogg ${ }^{2}$ \\ ${ }^{1}$ Irish Centre for Social Gerontology, National University of Ireland, Galway, Ireland and ${ }^{2} \mathrm{CNAV}$, Paris, \\ France \\ ${ }^{*}$ Corresponding author. Email: aine.nileime@nuigalway.ie
}

(Accepted 19 December 2018; first published online 31 January 2019)

This special issue focuses on the gendered impact of extending working life on the health and economic wellbeing of older workers. Since research on this increasingly important area of policy interest is well developed in some countries and newly emerging in others, a special issue provides an opportunity for scholars to access a variety of methods across different national contexts. Extending the working life is today widely promoted by international policy organisations such as the Organisation for Economic Co-operation and Development and adopted by many governments as a necessary policy response to ageing populations. However, these policies have been introduced rather quickly without adequate consideration of their gender and health implications, and the papers here explore aspects of the often complex effects. Most European and other Western countries have implemented reforms to their public pension systems, mainly by increasing the statutory pension age and applying actuarial discount factors for earlier retirement, but also by closing special early exit pathways, tightening eligibility rules and lengthening the required duration of contributions (OECD, 2017). The structural rise in the labour force participation of women and the growth of service and public-sector employment have also contributed to extending working life (European Commission, 2018). As a result, employment rates in many European countries have risen steadily in the age group 55-64 over the past ten years although the trends vary considerably between men and women and between countries. These trends indicate that besides the institutional context, other macro-level factors also influence the extension of the working life. For instance, the global financial crisis that began in 2008 had a more or less severe impact on the employment prospects of older workers in different countries. In Spain, the employment rate among older men fell from 58.5 per cent in 2004 to 54 per cent in 2015 whereas during the same period it almost doubled in Germany among women - from 34 to 61.2 per cent (Eurostat, 2016). The increasing precariousness of employment also poses global structural challenges to employment prospects for older workers 
(Vosko, 2008; Standing, 2011; Ní Léime et al., 2015). At the meso-level, the attitudes of employers to maintaining or hiring older workers strongly influence the possibility and nature of their participation in the labour market (Gringart et al., 2005; Loretto and White, 2006; Kluge and Krings, 2008; Conen et al., 2012). At the individual level, factors such as health and disability, and family configurations play an important role in determining the timing of retirement as well as the experience of working longer (Ogg and Renaut, 2006; Berntson and Marklund, 2007; Brugiavini et al., 2008; Calvo et al., 2013). All of these factors interact and give rise to different trends between countries and different experiences of men and women within countries. Extended working life policies have been introduced apparently without adequate consideration of the gender implications for different groups of older workers - those in precarious and secure occupations, physically demanding jobs or sedentary jobs.

As the title of the special issue implies, the gendered impacts of extended working life is the main preoccupation of the papers. Gender is critically important, given the significant evidence that gender norms, roles and responsibilities result in specific outcomes for older women. One of the most important gendered impacts of extended working life is that despite the increase in labour force participation, older women workers still have relatively poor economic outcomes in terms of earnings, pension-building and employment prospects. Gender pay gaps, part-time work and career breaks for bringing up children (as well as subsequent difficulties re-entering the labour market) combine to place women in a more disadvantaged position than men in terms of income in later life and old age. Re-entering the labour market in the second part of a working career after an absence due to illness, disability or a prolonged period of time as a home maker or carer, remains particularly problematic, and in particular women risk being 'blocked' in acquiring higherstatus employment due to a chequered work history. Recent data show that in the European Union, more than 20 per cent of women aged 65 and above are at risk of poverty or social exclusion, compared to 15 per cent of men aged 65 and above (European Commission, 2018). As a result, women may be increasingly obliged to work past retirement age in order to secure an adequate income in old age.

The papers in this special issue also explore how extended working life can be beneficial for some workers and punitive for others. Abolishing age barriers beyond which employers do not have a legal right to dismiss their workers can enable those who wish to remain employed to benefit from the positive aspects that paid work can provide - an income, self-fulfilment and the maintenance of social relations not to mention the economic benefits of retaining skilled workers. Providing the conditions under which these objectives can be achieved is a major challenge and the papers touch upon policies such as equal opportunity training that can promote extended working life. However, the main aim of the special issue is to draw attention to the actual and potential deleterious effects of extended working life policies an awareness that in our view is often missing in the design of current policy. With the main concern of governments slanted towards the reorganisation of pension systems, the unintended and often long-term consequences of extended working life for men and women remain largely unknown.

The special issue draws upon recent empirical research undertaken in several European countries as well as the United States of America (USA). In so doing, 
it adds to the growing literature and research that explores the 'complex social, economic and political circumstances [that] are all part of the empirical landscape of extended working lives' (Street, 2017: 3). Each paper covers a specific aspect of extending working life and examines the consequences for men and women. The principal dimensions addressed are:

- gender differences in access to and availability of training among older workers;

- occupational sector trajectories among women and their effect on extended working life;

- connections across dimensions of precarity that affect the work possibilities of men and women in later life;

- family and professional lifecourse events of men and women that intervene to influence later-life career patterns and the passage to retirement;

- organisational responses and their impact on the choices of older men and women to remain in the labour market;

- different pathways leading to temporary contracts among older workers;

- the temporality dimension of career paths and their influence on hierarchical relations and the formation of masculinities.

Access to training, whether for older workers in employment or those seeking employment, is an essential component of extending the working life. Yet time and again the evidence on the availability and uptake of training has shown that opportunities vary considerably. Moreover, strong gender differences exist in access to training over the lifecourse. These gender differences in training are explored in the first paper by Jelle Lössbroek and Jonas Radl. The research presented deals with access to training for older workers in the context of workplace practices as evidenced in several European countries, including Eastern Europe. The basis for the research is the well-known trend whereby employers assume that older workers have different strengths and weaknesses compared to their younger colleagues and that consequently older workers are less likely to participate in training than younger workers. However, the authors point out that although the literature has systematically demonstrated age differences in training, gender differences in access to training appear to be more complex than previously thought, especially in relation to older workers. Using data from the European Sustainable Workforce Survey (2015/2016), patterns of formal educational programmes available and on-the-job training for older workers are systematically examined in nine European countries. The analysis of these data shows that although rates of training participation for older men and women are comparable, women are more likely to pay for this training than men, a finding that adds to the existing literature on gender inequalities in the financing of training earlier in the lifecourse. A further important finding of the study is that whereas older women are more likely than men to be employees in organisations that offer higher levels of training (e.g. public services), they are employed in jobs that are less likely to offer training. The data also reveal that these gender differences are compounded by the attitudes of managers towards gender roles and the capabilities of older workers - 'working for a manager who holds ageist stereotypes does not affect older men, but older women receive less 
training in these departments'. Finally, the authors demonstrate that men with a female manager are more likely to receive training than women with a female manager. This finding is explained in terms of an over-compensation by women in managerial positions towards the training needs of men that is designed to limit the promotion of older women and thereby protect their minority status as female managers within the organisation. The paper concludes with a discussion of how the findings present the complex policy implications, i.e. promoting equal training opportunities for older men and women, and the proposition that older employees themselves should have more influence over training decisions.

The second paper, by Áine Ní Léime and Debra Street, compares the different experiences of women in two contrasting occupations - teaching and health care and in two different settings - the USA and Ireland. Each country has a gender pay gap and a larger gender pension gap prior to the introduction of policies to extend working lives. The research is firmly grounded in a lifecourse analytical approach that acknowledges the impact of gender on patterns of working careers and how different occupations have specific consequences for women in terms of extending the working life. The two occupational sectors selected for the paper represent secure occupations (teaching) as opposed to precarious occupations (health care), the latter occupations imposing physical demands that impact on the ability to continue working at later ages. Low-paid caring occupations are largely dominated by women in both countries and the interviews reveal how the trajectories of women in these occupations are more likely to lead to both poor financial and health outcomes in later life, especially in the USA. The evidence collected by the authors is compelling, since the narratives of the women clearly distinguish between the two occupations in terms of the ability to accumulate financial capital and maintain health. Clear policy implications result from the research, and the authors stress that these include not only questions relating to different pension eligibility rules for women experiencing physically demanding jobs, but also policy measures that address the current inability of women in low-paid precarious jobs to secure and improve adequate public pensions.

The theme of precarious occupations and working conditions is further developed in the paper by David Lain, Laura Airey, Wendy Loretto and Sarah Vickerstaff. As clearly demonstrated by the authors, current discourses of active ageing which promote agency, choice and control for individuals in planning their later careers and the timing of retirement belie stark realities of unstable labour markets with significant sectors of employment characterised by low pay. Consequently, it is becoming difficult to build up sufficient financial resources over the lifecourse, either in terms of savings or contributions towards a future pension. The result is, as the authors show, that individuals may have little choice over decisions regarding retirement, and that extending the working life for many is principally a matter of maintaining an income. In this way, older workers are increasingly joining the 'precariat', a term employed in the book of the same title (Standing, 2011). Lain et al. build on this framework to propose a new theoretical model from which the experience of extending the working life can be explained. The model stipulates that the influence of the availability and conditions of employment of older workers on the precariousness of individual's lives should be understood with reference to the domains of the welfare state and the household. 
Using recent pension reform trends in the United Kingdom, the authors show that institutional constraints for public pension eligibility rules and access to disability benefits have particular consequences for women, most notably single women. Applying this theoretical framework to a corpus of qualitative interviews of older employees in local government and hospitality organisations, the research shows how the intersection of precariousness in jobs, welfare states and households in turn creates a sense of 'ontological precarity' among older workers. Importantly, the research demonstrates how each of these three domains may either buffer or promote precariousness and therefore more attention should be paid in future research to the interaction between these and other important domains of precariousness over the lifecourse and the consequences for extending the working life.

The paper by Sylvie Renaut and Jim Ogg identifies the differential impact of important lifecourse events that can determine the timing of exit from the labour market of French men and women in later life. Using a lifecourse perspective, the research associates key early and mid-lifecourse events of men and women with economic activity in later life and pathways to retirement. As in the previous papers, the interaction between individual trajectories and institutional welfare state contexts forms an important part of the analysis. Data are from the three waves $(2005,2008$ and 2011) of the French version of the Gender and Generations survey. The authors observe that women whose family formation occurred early, together with women who had an absence of family events (such as absence of partnership or childlessness), were much more likely to be economically active in later life than men with the same characteristics. Moreover, gender differences of opportunity exist, since the results show that women are more likely to accumulate the effects of interrupted professional careers and are also more liable than men to be in lower-qualified jobs. The type of job category, occupational profession and employment sector has a significant impact on economic activity in later life and on pathways to retirement. In the French context, the institutional legal and administrative frameworks relating to occupational sectors 'push' or 'retain' certain employment categories in and out of economic activity. Institutionalised (standardised) lifecourse patterns exist simultaneously with individualised (destandardised) patterns. As far as implications are concerned, the authors suggest that institutional reforms directed towards extending working life can only be successful if men and women are in stable jobs towards the end of their working lives.

In her paper on the experience of Belgian temporary workers at the end of their working life, Nathalie Burnay examines a growing trend which has all the hallmarks of precariousness but which on closer examination proves to be a complex phenomenon with different consequences for men and women. In Belgium, there has been a significant increase in temporary work contracts during the past 20 years, and older workers are increasingly entering this sector of the labour market. Interviews with older workers $(\mathrm{N}=45)$ on temporary work contracts form the basis of an in-depth analysis on how this temporary work is experienced and in particular whether it is undertaken by choice or constraint. Here, the importance of understanding the impact of lifecourse events and 'turning points' on the experience of temporary work is crucial. Four categories of temporary work profiles are identified: a first group characterised by enduring precarity over the lifecourse and difficulties in securing a long-term contract; a second group also characterised by 
precariousness but for whom a particular lifecourse event has disrupted a career trajectory; a third group for whom temporary work is largely a matter of choice and accompanied by a strong work ethic; and a fourth group where temporary work is also chosen but combined with a lifestyle that is less work orientated and one based on other pursuits. The analysis shows above all the gendered characteristics of these four groups. Men and women are equally present in the first group, but the negative consequences of a life-time associated with temporary work appears to be a more common experience among men; a disrupted career trajectory leading to temporary work, such as a redundancy, can be particularly harsh for men; and a chosen pattern of temporary work is mainly one which is experienced by women. These gendered experiences of temporary work are important in terms of policies extending the working life. On the one hand, the research shows how the experience of the temporary contract older worker is influenced by social inequalities in the progression of the lifecourse. On the other hand, as the author suggests in her conclusion, the increase in temporary work contracts is one facet of a societal shift away from the work ethic to one of self-fulfilment. Older workers are not immune to this trend and this cultural shift will increasingly impact on the way in which older workers engage in the labour market and exit from it. Thus, the paper highlights the underlying tensions between groups for whom there is a choice concerning work and careers, and those for whom choice is absent.

The final paper in the special issue focuses on the dimension of temporality to understand extending the working life. Drawing on the notion of career timetables, whereby normative representations of career advancement or set-backs play an important role in the organisational processes relating to extending the working life, Clary Krekula employs a corpus of in-depth interviews with Swedish men working in the metal industry. The analysis shows that internal work mobility norms disadvantage older men and limit their opportunities for developing or re-orientating their work towards less physically demanding tasks. Importantly, the analysis demonstrates the way in which the industry structures normative expectations around older workers, thereby defining the 'problems' relating to older workers as the responsibility of the individual. The author concludes that temporal regimes 'create an age normality against which the older workers are marked as problematic in terms of mobility in their organisation'.

The six contributions to the special issue on the gendered impacts of extended working life reinforce the need for further research. As the papers clearly indicate, the conjuncture of rising precariousness and the extension of the working life results in complex and differentiated experiences that are highly gendered. These aspects are too often absent from discourses on extended working life where the notion of 'choice' is uncritically employed. The papers interrogate the simplistic notion that introducing one-size-fits-all policies such as raising the state pension age across the board in Western countries is an adequate policy response to population ageing and suggest that there is a need for more nuanced policy responses that will not result in exacerbating existing gendered work and pension inequalities. There is a need for further cross-national research to explore how different welfare state and socio-economic contexts shape extended working life in different ways. The issues of ill-health in older workers and temporary and precarious employment warrant more in-depth investigation in various country contexts. The new 
conceptual model in the paper by Lain et al. points to the need for research and policy that recognises the interconnectedness of domains of precarity. There is room for further research attention to gendered training needs at the individual country level. Finally, the extent to which organisational norms can restrict older workers' possibilities of career progression or even continuation deserves further investigation. We hope that research on this topic will continue to expose the inequalities associated with working longer and in turn contribute to the ultimate aim of reducing them.

Author ORCIDs. (D) Áine Ní Léime 0000-0002-3395-616X

Acknowledgements. Each paper in this special issue is based on work from COST Action IS1409 Gender and Health Impacts of Policies Extending Working Life in Western Countries, supported by COST (European Cooperation in Science and Technology).
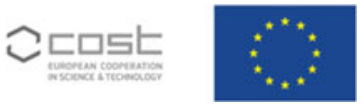

\section{References}

Berntson E and Marklund S (2007) The relationship between perceived employability and subsequent health. Work \& Stress 21, 279-292.

Brugiavini A, Croda E and Dewey M (2008) Retirement and mental health. In Boersch-Supan A, Brugiavini A, Jurges H, Kapteyn A, Mackenbach J, Siegriest J and Weber G (eds), Health, Ageing and Retirement in Europe (2004-2007), Vol. 1. Mannheim, Germany: MEA Research Institute, pp. 247-255.

Calvo E, Sarkisian N and Tamborini CR (2013) Causal effects of retirement timing on subjective physical and emotional health. Journals of Gerontology: Psychological Sciences and Social Sciences 68B, 73-84.

Conen WS, Henkens K and Schippers J (2012) Employers' attitudes and actions towards the extension of working lives in Europe. International Journal of Manpower 33, 648-665.

European Commission (2018) Pension Adequacy Reports, Vols 1 and 2. Brussels: Directorate-General for Employement, Social Affairs and Inclusion.

Eurostat (2016) The Employment Rate of Older Workers. Available at http://ec.europa.eu/eurostat/tgm/ table.do?tab=table\&init $=1$ \&plugin $=1$ \&language $=$ en\&pcode $=$ tsdde100.

Gringart E, Helmes E and Speelman CP (2005) Exploring attitudes towards older workers among Australian employers. Journal of Aging and Social Policy 17, 85-103.

Kluge A and Krings F (2008) Attitudes towards older workers and Human Resource practices. Swiss Journal of Psychology 67, 61-64.

Loretto W and White $\mathbf{P}$ (2006) Employers' attitudes, practices and policies towards older workers. Human Resource Management Journal 16, 313-330.

Ní Léime Á, Duvvury N and Callan A (2015) Delayed retirement: gender, ageing and work in austerity. In Walsh K, Carney G and Ní Léime Á (eds), Ageing Through Austerity: Critical Perspectives from Ireland. Bristol, UK: Policy Press, pp. 63-78.

OECD (2017) Pensions at a Glance 2017: OECD and G20 Indicators. Paris: OECD Publishing.

Ogg J and Renaut S (2006) The support of parents in old age by those born during 1945-1954: a European perspective. Ageing \& Society 26, 723-743.

Standing G (2011) The Precariat: The Dangerous New Class. London: Bloomsbury Academic.

Street D (2017) The empirical landscape of extended working lives. In Ní Léime Á, Street D, Vickerstaff S, Krekula C and Loretto W (eds), Gender and Extended Working Life: Cross-national Perspectives. Bristol, UK: Policy Press, p. 3-26.

Vosko LF (2008) Temporary work in transnational labor regulation: SER-centrism and the risk of exacerbating gendered precariousness. Social Indicators Research 88, 131-145.

Cite this article: Ní Léime Á, Ogg J (2019). Gendered impacts of extended working life on the health and economic wellbeing of older workers. Ageing \& Society 39, 2163-2169. https://doi.org/10.1017/ S0144686X18001800 